\title{
Tourette syndrome: current data, comorbidities, and therapeutic approach in children
}

\author{
R Rizzo ${ }^{1,2}$ \\ From 70th Congress of the Italian Society of Pediatrics, Joint National Meeting SIP, SICUPP, SITIP \\ Palermo, Italy. 11-14 June 2014
}

Tourette syndrome (TS) is the primary tic disorder with an estimated prevalence close to $1 \%$ between 5 and 18 years of age [1]. Motor and phonic tics are the core features of TS [2]. In addition to their well-characterized phenomenology, tics display a peculiar variability over time, which is strongly influenced by a variety of contextual factors. A relevant proportion of patients with TS display complex, tic-like, repetitive behaviors that include echophenomena, coprophenomena, and nonobscene socially inappropriate behaviors (NOSIBs). Co-morbid conditions are attention deficit hyperactivity disorder (ADHD), obsessive compulsive behaviours/disorder $(\mathrm{OCB} / \mathrm{D})$ and autistic spectrum disorder (ASD); co-existent psychopathologies include depression, anxiety, oppositional defiant disorder (ODD), conduct disorder (CD) and personality disorders (PDs) [3]. The complexity of the Tourette spectrum has been confirmed by cluster and factor analytical approaches [4]. It is suggested that TS is not a unitary condition and that one phenotype ("Pure TS" [tics only]) occurs in about 10-14 \% [5]. The presence of comorbid attention deficit hyperactivity disorder (ADHD) is the main determinant of cognitive dysfunction in TS patients and influences heavily also the risk of developing disruptive behaviors [6].The burden of behavioral comorbidities is very important in determining significant impairment, poor self-esteem, and a low quality of life $[7,8]$.While the evidence for a genetic contribution is strong, several genes, including SLITRK1, LIM homeobox (LHX6,LHX8), and HDC have been suggested to be responsible for the different clinical phenotypes $[9,10]$. However its exact nature has yet to be clarified fully. Aetiological factors include genetic vulnerability pre- and peri-natal difficulties (PNDs), and probably neuro-immunological factors. Neuro-imaging are helpful

\footnotetext{
Correspondence: rerizzo@unict.it

${ }^{1}$ Child and Adolescent Neurology and Psychiatry, Department of Medical and Pediatric Science

Full list of author information is available at the end of the article
}

to exclude other conditions, and although abnormalities are described, in an individual patient, they are not diagnostic. Treatment includes psycho-education and reassurance, medications, target-specific botulinum toxin injections [11] and in a few severe refractory adult cases, deep brain stimulation life [12].This review will summarise and highlight selected main findings from the author's clinic.

\section{Authors' details}

${ }^{1}$ Child and Adolescent Neurology and Psychiatry, Department of Medical and Pediatric Science. ${ }^{2}$ Catania University, Via S.Sofia 78 Catania, 95123 Italy.

Published: 11 August 2014

\section{References}

1. Robertson MM: The prevalence and epidemiology of Gilles de la Tourette syndrome. Part 1: the epidemiological and prevalence studies. J Psychosom Res 2008, 65:461-72.

2. American Psychiatric Association: Diagnostic and Statistical Manual of Mental Disorders. Washington DC, 52013.

3. Robertson MM: Movement disorders: Tourette syndrome-beyond swearing and sex? Nat Rev Neurol 2014, 10:6-8.

4. Cavanna AE, Critchley HD, Orth M, Stern JS, Young MB, Robertson MM: Dissecting the Gilles de la Tourette spectrum: a factor analytic study on 639 patients. J Neurol Neurosurg Psychiatry 2011, 82:1320-3.

5. Rizzo R, Gulisano M, Calì PV, Curatolo P: Long term clinical course of Tourette syndrome. Brain Dev 2012, 34:667-73.

6. Müller-Vahl K, Dodel I, Müller N, Münchau A, Reece JP, Balzer-Geldsetzer M, Dodel R, Oertel WH: Health-related quality of life in patients with Gilles de la Tourette's syndrome. Mov Disord 2010, 25:309-14.

7. Rizzo R, Curatolo P, Gulisano M, Virzì M, Arpino C, Robertson MM: Disentangling the effects of Tourette syndrome and attention deficit hyperactivity disorder on cognitive and behavioral phenotypes. Brain Dev 2007, 29:413-420.

8. Eddy CM, Rizzo R, Gulisano M, Agodi A, Barchitta M, Calí P, Robertson MM, Cavanna AE: Quality of life in young people with Tourette syndrome: a controlled study. J Neurol 2011, 258:291-301.

9. Karagiannidis R, Rizzo Z, Tarnok Z, Wolanczyk T, Hebebrand J, Nöthen MM, Lehmkuhl G, Farkas L, Nagy P, Barta C, Szymanska U, Panteloglou G, Miranda DM, Feng Y, Sandor P, Barr C, TSGeneSEE, Paschou P: Replication of association between a SLITRK1 haplotype and Tourette syndrome in a large sample of families. Mol Psychiatry 2012, 17:665-668.

10. Paschou P, Stylianopoulou E, Karagiannidis I, Rizzo R, Tarnok Z, Wolancyzk T, Hebebrand J, Nöthen MM, Lehmkuhl G, Farkas L, Nagy P, Szymanska U, Lykidis D, Androutsos C, Szymanska U, Tsironi V, Koumoula A, Barta C, Klidonas C, Ypsilantis P, Simopoulos P, Skavdis G, Grigoriou M, TSGeneSEE: 
Evaluation of the LIM homeobox genes LHX6 and LHX8 as candidates for Tourette syndrome. Genes Brain Behav 2012, 11:444-451.

11. Roessner V, Plessen K, Rothenberger A, Ludolph AG, Rizzo R, Skov L, Strand G, Stern JS, Termine C, Hoekstra PJ: ESSTS Guidelines Group. European clinical guidelines for Tourette syndrome and other tic disorders. Part II: pharmacological treatment. Eur Child Adolesc Psychiatry 2011, 20:173-96.

12. Müller-Vahl KR, Cath DC, Cavanna AE, Dehning S, Porta M, Robertson MM, Visser-Vandewalle V: ESSTS Guidelines Group European clinical guidelines for Tourette syndrome and other tic disorders. Part IV: deep brain stimulation. Eur Child Adolesc Psychiatry 2011, 20:209-17.

doi:10.1186/1824-7288-40-S1-A68

Cite this article as: Rizzo: Tourette syndrome: current data

comorbidities, and therapeutic approach in children. Italian Journal of Pediatrics 2014 40(Suppl 1):A68.

\section{Submit your next manuscript to BioMed Central} and take full advantage of:

- Convenient online submission

- Thorough peer review

- No space constraints or color figure charges

- Immediate publication on acceptance

- Inclusion in PubMed, CAS, Scopus and Google Scholar

- Research which is freely available for redistribution

Submit your manuscript at www.biomedcentral.com/submit 